\author{
ALICJA LIMBURSKA \\ ORCID: 0000-0002-6722-0249 \\ Uniwersytet Wrocławski \\ Katedra Prawa karnego Materialnego \\ KONRAD LIPIŃSKI \\ ORCID: 0000-0001-5342-4905 \\ Uniwersytet Wrocławski \\ Katedra Prawa Karnego Materialnego
}

\title{
PROBLEM (NIE)RACJONALNOŚCI PROJEKTODAWCY NA PRZYKŁADZIE WYBRANYCH UREGULOWAŃ USTAWY NOWELIZUJĄCEJ KODEKS KARNY Z 13 CZERWCA 2019 ROKU*
}

\begin{abstract}
Abstrakt: Wychodząc od analizy treści założenia o racjonalności prawodawcy, autorzy podejmują próbę odniesienia zdekodowanego standardu do specyfiki unormowań prawa karnego. W dalszych rozważaniach, dla których podstawą jest treść projektu ustawy z dnia 13 czerwca 2019 roku o zmianie ustawy - Kodeks karny i niektórych innych ustaw, koncentrują się na zagadnieniu (nie)racjonalności projektodawcy oraz wynikających zeń poszczególnych postulatach formułowanych wobec prawodawcy faktycznego.
\end{abstract}

Słowa kluczowe: prawo karne, kodeks karny, projektodawca, racjonalność, racjonalny ustawodawca

Jedno z podstawowych założeń czynionych na gruncie nauk prawnych przewiduje, że podmiot tworzący prawo - ujmowany w kategoriach zdepersonalizowanego prawodawcy — jest racjonalny, a być może nawet doskonały. Bez obawy o popełnienie większego błędu można wręcz zaryzykować tezę, że założenie o racjonalności prawodawcy da się aktualnie określić paradygmatem prawoznawstwa $^{1}$. Jest to rzecz jasna założenie kontrfaktyczne, idealizacyjne. Koncepcja pra-

* Ustawa z dnia 13 czerwca 2019 roku o zmianie ustawy — Kodeks karny i niektórych innych ustaw uchwalona przez Sejm Rzeczpospolitej Polskiej na 82. posiedzeniu w dniu 13 czerwca 2019 roku. W toku prac legislacyjnych projekt ustawy występował pod postacią druku sejmowego nr 3451 (Sejm VIII kadencji). 
wodawcy racjonalnego (oraz doskonałego) została stworzona przez L. Nowaka ${ }^{2}$, a rozwijana była przede wszystkim przez teoretyków ośrodka poznańskiego ${ }^{3}$. Nie podejmując się próby jej bliższego scharakteryzowania, a poprzestając na elementach, które z perspektywy dalszych rozważań mogą okazać się istotne, stwierdzić wystarczy, że pod pojęciem racjonalnego prawodawcy rozumie się zdepersonalizowanego autora tekstu prawnego, ,podstawianego" przez prawników w miejsce jego autentycznego autora. W konsekwencji prawodawca traktowany jest jako konstrukt teoretyczny, kierujący się przede wszystkim zasadą racjonalności. W prawoznawstwie posługujemy się dodatkowo licznymi założeniami idealizującymi dotyczącymi świadomości prawodawcy oraz zewnętrznych warunków jego działania. Zgodnie z nimi wiedza prawodawcy jest niesprzeczna, ma charakter systemowy, prawodawca dysponuje doskonałą kompetencją językową, jego wiedza jest aktualna, jego preferencje mają charakter asymetryczny oraz przechodni, a jego system ocen jest pełny ${ }^{4}$. W procesie wykładni prawa założenia, zgodnie z którym prawodawca jest racjonalny, nie usuwa się nigdy ${ }^{5}$.

Założeniem o racjonalności prawodawcy posługujemy się oczywiście również $\mathrm{w}$ rozważaniach prowadzonych $\mathrm{w}$ ramach szczegółowych nauk prawnych, w tym w prawie karnym. Podkreślić przy tym trzeba, że prawodawca - ingerując $\mathrm{w}$ delikatną materię prawa karnego, wkraczającą w maksymalnym możliwym stopniu w prawa i wolności jednostki — winien wykazać się szczególną ostrożnością, odstępując od władczej ingerencji tam, gdzie nie jest to niezbędne. Rzecz bowiem w tym, że — jak zauważa A. Zoll — błędy popełnione w nowelizowaniu prawa karnego mogą prowadzić do strat wyrażających się nie tylko w orzeczeniach niewywołujących zgoła żadnych efektów w ograniczeniu przestępczości, lecz także do daleko idących negatywnych konsekwencji w losach indywidualnych osób, niesłusznie uczynionych przestępcami mimo braku dostatecznych ku temu podstaw 6 . Mówiąc inaczej, braki w zakresie racjonalności i skuteczności na

${ }^{1}$ P. Kantor-Kozdrowicki, Racjonalność prawodawcy jako paradygmat nauk prawnych, „Folia Iuridica Universitatis Wratislaviensis" 7, 2018, s. 95 n.

2 Zob. przede wszystkim L. Nowak, Próba metodologicznej charakterystyki prawoznawstwa, Poznań 1968; idem, Interpretacja prawnicza. Studium z metodologii prawoznawstwa, Warszawa 1973. Co do różnicy między normodawcą racjonalnym a doskonałym zob. L. Nowak, Interpretacja ..., s. 43 46.

3 Zob. m.in. opracowania znajdujące się w zbiorze Szkice z teorii prawa i szczegółowych nauk prawnych, red. S. Wronkowska, M. Zieliński, Poznań 1990.

${ }^{4}$ A. Kozak, [w:] Wprowadzenie do nauk prawnych. Leksykon tematyczny, red. A. Bator, Warszawa 2008, s. 62-63.

5 Jak bowiem stwierdza L. Nowak, „Nie ma [...] wśród najbardziej nawet rozbudowanych reguł logiki prawniczej takich, które by usuwały supozycję jego [tj. prawodawcy - A.L., K.L.] racjonalności (maksymalizacji przyjętych preferencji). W toku wykładni prawa wymogu racjonalności prawodawcy nie usuwa się nigdy" - idem, O ukrytej jedności nauk społecznych i nauk przyrodniczych, „Nauka” 1998, nr 1, s. 17-18.

6 A. Zoll, Potrzeba racjonalności w reformowaniu prawa karnego, [w:] Teoretyczne i praktyczne problemy wspótczesnego prawa karnego, red. T. Bojarski et al., Lublin 2011, s. 29. 
gruncie prawa karnego mają szczególne implikacje i właśnie z tego powodu w tej gałęzi prawa wymagania te formułowane są najdobitniej ${ }^{7}$. Względy te przemawiają również za tym, że prawo karne powinno należeć do tych gałęzi prawa, które zmianom ulegają relatywnie rzadko - w szczególności zmianom tak rozległym i głęboko tnącym strukturę kodeksu karnego, że mogłyby aspirować do miana już nie tyle nowelizacji (których dotychczasowa liczba może skądinąd przyprawiać o zawrót głowy), ile reformy.

Skoro jednak analizując tekst prawny, wychodzimy z założenia, że jego autorem jest wyidealizowany prawodawca, to mamy też pełne prawo zakładać, że podmiot ten tworzy prawo w sposób racjonalny nie tylko na płaszczyźnie językowej (z uwagi na doskonałe posługiwanie się językiem), lecz także na wcześniejszym niejako etapie, a zatem podejmując decyzję o wysłowieniu konkretnego zespołu norm w tekście aktu prawnego. Innymi słowy, wychodzimy z założenia, że ustawodawca nie tylko trafnie wysławia swoją wolę, ale też że wola ta wiedziona jest rzeczywistą (i odpowiednio rozpoznaną) potrzebą wpływania za pomocą prawa na zastane stosunki społeczne. Opiera się on na ich trafnej diagnozie, na wyborze sensownych i możliwych w demokratycznym państwie prawnym środków do zrealizowania zamierzonych celów, a zarazem na trafnej prognozie, że obrany przezeń cel da się w sposób najpełniejszy zrealizować za pomocą takich właśnie środków.

Nawiązujemy tu oczywiście do modelu racjonalnego stanowienia prawa w ujęciu J. Wróblewskiego. Model ten — zgodnie z deklaracją autora - polega na wyliczeniu i analizie podstawowych problemów, które powinny zostać rozstrzygnięte przez prawodawcę, jeżeli jego działanie miałoby mieć charakter racjonalny ${ }^{8}$. Warto podkreślić, że możemy w tym kontekście mówić o racjonalności w dwu ujęciach. Pod pojęciem racjonalności w sensie rzeczowym rozumie się przystosowanie określonego działania (racjonalnego) do obiektywnie rozumianej prawdy. $Z$ racjonalnością $w$ sensie metodologicznym mamy zaś do czynienia, gdy podmiot wykonujący dane działanie postępuje wedle wskazań posiadanej przezeń wiedzy rozumianej jako „ogół tych posiadanych informacji, którym zważywszy na sposób ich uzasadnienia, ów osobnik winien przypisać prawdopodobieństwo dostateczne do tego, by postępować tak, jak gdyby były prawdziwe" .

Nie wymagając od projektodawcy (oraz faktycznego ustawodawcy), aby jego działania okazały się dostosowane do bezwzględnie i obiektywnie prawdziwych okoliczności, w dalszych rozważaniach analizie poddamy przede wszystkim dostosowanie dobranych przez projektodawcę środków do deklarowanej przezeń wiedzy o zjawiskach, w które zamierza ingerować. Mając tę perspektywę na względzie, na model racjonalnego tworzenia prawa składają się kolejno: (1) określenie celu działalności prawotwórczej; (2) ustalenie prawidłowości -

${ }^{7}$ B. Janiszewski, Rozważania o „,racjonalności” w dziedzinie prawa karnego, „Ruch Prawniczy, Ekonomiczny i Socjologiczny" 1996, nr 4, s. 11.

8 J. Wróblewski, Teoria racjonalnego tworzenia prawa, Warszawa 1985, s. 132.

${ }^{9}$ T. Kotarbiński, Traktat o dobrej robocie, Wrocław-Warszawa-Kraków 1982, s. 123-124. 
potencjalnych środków do realizacji tego celu; (3) ustalenie, jakie ze środków potencjalnych mogą być środkami prawnymi realizacji celu (dodajmy — w demokratycznym państwie prawnym); (4) wybór określonego środka prawnego oraz wreszcie - (5) ustanowienie określonych przepisów prawnych ${ }^{10}$. Jest przy tym oczywiste, że ustanowienie danych przepisów musi poprzedzić ich odpowiednie zaprojektowanie.

Jak już jednak wspomnieliśmy, założenia idealizujące prawodawcę mają charakter kontrfaktyczny. Nie ulega bowiem wątpliwości, że rzeczywisty prawodawca, a w szczególności konkretne, nie zawsze zresztą możliwe do zidentyfikowania osoby biorące udział w projektowaniu, a następnie uchwalaniu aktu prawnego ${ }^{11}$, bynajmniej doskonałe nie są. Nie oznacza to jednak, że w procesie ustawodawczym prawodawca racjonalny nie mógłby być wzorem prawodawcy faktycznego. Jest wręcz przeciwnie - mamy pełne prawo oczekiwać, że ustawodawca faktyczny (a na pewnym etapie tworzenia aktu prawnego — jego projektodawca) będzie starał się zbliżyć do modelu prawodawcy racjonalnego, choćbyśmy nawet mieli pewność, że do tak wysoko zawieszonej „poprzeczki” nigdy nie uda mu się „doskoczyć".

Wydaje się, że w toku analizy uchwalanych (będących przedmiotem procesu legislacyjnego) przepisów prawnych dokonujemy interpretacji w taki sposób, jak gdyby zostały ustanowione przez racjonalnego prawodawcę. Różnica polega wszakże na tym, że wobec dostrzeżenia pewnych błędów, dwuznaczności czy niespójności w projekcie aktu prawnego nikt nie zabroni nam stwierdzićc ${ }^{12}$, że pro-

10 J. Wróblewski, op. cit., s. 135 n.; W. Lang, J. Wróblewski, S. Zawadzki, Teoria państwa i prawa, Warszawa 1986, s. 421-422.

11 Pod pojęciem ,prawodawcy faktycznego” czy socjologicznego rozumie się bowiem ludzi biorących udział w procesie przygotowywania i stanowienia aktów prawnych, wywierających rzeczywisty wpływ na ukształtowanie ich określonej treści oraz nadających im określony kształt formalny. Zob. S. Wronkowska, Prawodawca racjonalny jako wzór dla prawodawcy faktycznego, [w:] Szkice z teorii prawa..., s. 118.

12 Jedynie na marginesie, na zasadzie swoistego kontrdowodu anegdotycznego, przypomnieć jednak trzeba pojawiające się $\mathrm{w}$ związku z opiniami wyrażanymi $\mathrm{w}$ toku procesu legislacyjnego oficjalne wypowiedzi zawarte na stronach internetowych Ministerstwa Sprawiedliwości, stosownie do których „Zaufanie do wymiaru sprawiedliwości to fundament państwa prawa, państwa demokratycznego i uczciwego. Dlatego państwo nie może tolerować kłamstwa, które uderza w jego podstawy, które sprawia, że zaufanie obywateli zostanie zachwiane. Szczególnie, gdy kłamią prawnicy, profesorowie jednej z najznamienitszych uczelni w Polsce, a nawet na świecie. Uczeni Uniwersytetu Jagiellońskiego w Krakowie, którzy byli do tej pory niekwestionowanymi autorytetami w dziedzinie prawa [...]. Ta opinia jest nieprawdziwa. Jest kłamstwem [...]. Ministerstwo Sprawiedliwości nie zna powodów, dla których profesorowie i doktorowie znamienitej krakowskiej uczelni skłamali w swojej opinii" - https://www.gov.pl/web/sprawiedliwosc/ministerstwo-sprawiedliwosci-wytoczy-proces-cywilny (dostęp: 26.02.2020). Pierwotnie w komunikacie znajdowało się również stwierdzenie: „Ministerstwo Sprawiedliwości pozwie za kłamstwo profesorów i doktorantów krakowskiego uniwersytetu do sądu, w obronie swojego dobrego imienia, w obronie polskiego wymiaru sprawiedliwości, a także w obronie renomy samego Uniwersytetu Jagiellońskiego. Są bowiem granice krytyki i politycznych sporów, których przekraczać nie wolno" — zob. M. Pankowska, 
jektodawca - inaczej niż ustawodawca — jest jednak nieidealny, niedoskonały, a być może nawet nieracjonalny, co pozwoli na zmodyfikowanie jego wypowiedzi — przyjmującej postać projektu ustawy ujętego w ramy druku sejmowego - jeszcze przed uchwaleniem tekstu prawnego. Pomimo bowiem tego, że wypowiedzi projektodawcy odczytujemy w podobny sposób, jak czynilibyśmy to w wypadku ustawodawcy, mamy prawo (a w pewnym pozanormatywnym sensie - nawet obowiązek) stwierdzić, że projektodawca się myli, a jego wypowiedzi należy skorygować, a być może nawet — w sytuacji, w której nie są zachowane już wstępne warunki racjonalnego tworzenia prawa, determinujące decyzję o wprowadzeniu zmiany normatywnej - że nowelizacji w ogóle należy poniechać.

Wychodząc z takiego założenia, zwróćmy się zatem ku ustawie z dnia 13 czerwca 2019 roku o zmianie ustawy — Kodeks karny oraz niektórych innych ustaw, która 28 czerwca 2019 roku na podstawie art. 122 ust. 3 Konstytucji RP została skierowana przez Prezydenta do Trybunału Konstytucyjnego. Nietrudno zauważyć, że ustawa ta w swych założeniach ma niezwykle głęboko ingerować w unormowania kodeksu karnego, a co za tym idzie — w jej wypadku ze szczególną mocą aktualizują się standardy racjonalności nie tylko na etapie stanowienia, lecz także projektowania aktu prawnego. Rzecz bowiem w tym, że posługując się porównaniem ustawy z 13 czerwca 2019 roku do noweli, która weszła w życie 1 lipca 2015 roku $^{13}$, można by się zastanawiać, czy nie mamy do czynienia ze swoistą (ponowną) rekodyfikacją, zmierzającą wszelako w całkowicie odmiennym kierunku od tej uchwalonej cztery lata wcześniej ${ }^{14}$. Mielibyśmy przeto do czynienia z kolejną w ciągu kilku lat kompleksową czy niemalże paradygmatyczną zmianą idei leżącej u podstaw prawnokarnej regulacji normatywnej w kierunku jej zdecydowanie dalej idącej punitywności (co projektodawca wprost wszak deklaruje już na pierwszej stronie uzasadnienia dołączonego do projektu ustawy ${ }^{15}$ ). Nasuwać się musi w związku z tym pytanie, czy i kiedy modyfikacje tego rodzaju

Ministerstwo Sprawiedliwości zapowiada pozew dla krakowskich karnistów. Za krytykę zmian w kodeksie, ,oko.press” 15.06.2019, https://oko.press/ministerstwo-sprawiedliwosci-zapowiada-pozew-dla-krakowskich-karnistow-za-krytyke-zmian-w-kodeksie/ (dostęp: 26.02.2020).

13 Ustawa z dnia 20 lutego 2015 roku o zmianie ustawy — Kodeks karny oraz niektórych innych ustaw (Dz.U. z 2015 r. poz. 396).

14 Pojęciem rekodyfikacji w stosunku do ustawy z 2015 roku operują P. Kardas i J. Giezek, na wiele sposobów uzasadniając, że na takie spostrzeżenie pozwalały zakres nowelizacji, jej charakter i prognozowane konsekwencje. Przykładając tę samą miarę do noweli z 13 czerwca 2019 roku, dojdziemy do wniosku, że i w tym wypadku określenie „rekodyfikacja” jawi się jako adekwatne, choć można rzecz jasna ubolewać nad tym, że w ciągu czterech lat wprowadza się dwie tak daleko idące zmiany o charakterze modelowym, choć o przeciwnych wektorach. Zob. eidem, Nowa filozofia karania, czyli o założeniach i zasadniczych elementach nowelizacji kodeksu karnego, „Palestra” 2015, nr 7-8, s. 10 .

15 Uzasadnienie projektu ustawy o zmianie ustawy — Kodeks karny oraz niektórych innych ustaw (druk sejmowy nr 3451, Sejm VIII kadencji), s. 1; dalej: uzasadnienie projektu. 
bylibyśmy w stanie uznać za konieczne, a przynajmniej satysfakcjonująco uzasadnione.

Próbując na tak zadane pytanie udzielić odpowiedzi, warto przytoczyć refleksję A. Zolla, który z trudnego do zdezawuowania postulatu stabilności prawa karnego wyprowadza swoisty katalog okoliczności uzasadniających wprowadzenie zmian w tej gałęzi prawa. Zmiany takie — w szczególności gdy mówimy o zmianach o charakterze modelowym - można by rozważać: (1) wobec zasadniczej zmiany w społecznej ocenie poszczególnych wartości na skutek gruntownej zmiany ustroju politycznego; (2) wobec konieczności dostosowania prawa krajowego do standardów narzucanych przez Unię Europejską lub - ujmijmy tę przesłankę szerzej — zobowiązań o charakterze międzynarodowym; (3) w sytuacji, w której tekst ustawy zawiera dotychczas niedostrzeżony i niemożliwy do wyeliminowania w drodze wykładni błąd lub lukę, a w końcu (4) w wyniku dokonywanej w kilkuletnich odstępach czasu kontroli tekstu prawnego pod kątem potrzeby dokonania zmian wynikających z przeobrażeń stosunków społecznych ${ }^{16}$. Do katalogu tego można by dodać jeszcze sytuacje zmian struktury danego rodzaju przestępczości, przyjmujące postać utrzymującego się trendu albo też nieznajdujące wytłumaczenia załamanie się dotychczasowej polityki ścigania i karania ${ }^{17}$. Jeśliby zaś poszukiwać racji leżących u podstaw projektowanej nowelizacji w jednym z wymienionych przypadków, zapewne jako najbardziej intuicyjna jawiłaby się sytuacja czwarta. Nie mamy wszak do czynienia z gwałtowną zmianą ustroju politycznego, określonego stopnia punitywności prawa karnego nie wymagają zobowiązania międzynarodowe, zakres zaś projektowanych rozwiązań nie pozwala na przyjęcie, że projektodawca postanowił „załatać” pojedyncze luki w tekście prawnym. Nic nie wskazuje również na to, abyśmy mieli do czynienia z nagłym załamaniem polityki ścigania i karania. Analizowaną nowelizację uzasadnić mogłyby przeto dostrzeżone zmiany wynikające z przeobrażeń stosunków społecznych. Można by jednak mieć uzasadnione wątpliwości, czy projekt zmian, a w szczególności jego uzasadnienie, pozwalają na sformułowanie tezy, że przesłanka ta się zaktualizowała $^{18}$.

Przechodząc do zagadnień nieco bardziej szczegółowych, należy wskazać, że jednym $\mathrm{z}$ wymogów czy postulatów stawianych racjonalnemu prawodawcy jest oparte na założeniu konsekwencji jego ocen twierdzenie, zgodnie z którym

16 A. Zoll, op. cit., s. 32-33.

17 M. Filar, „Druga” nowelizacja kodeksu karnego dotyczaca tzw. przestęstw seksualnych, „Państwo i Prawo” 2006, nr 3, s. 39.

18 Zob. w szczególności uwagi zawarte we wstępnej części opinii Katedry Prawa Karnego Materialnego Wydziału Prawa, Administracji i Ekonomii Uniwersytetu Wrocławskiego — J. Giezek, K. Lipiński, Uwagi wprowadzające, [w:] J. Giezek et al., Opinia na temat projektu zmian przepisów kodeksu karnego (uchwała Senatu Rzeczypospolitej Polskiej z dnia 24 maja 2019 roku), s. 1-6, https:// www.rpo.gov.pl/sites/default/files/Opinia\%20Katedry\%20Prawa\%20Karnego\%20Materialnego\%20 WPAE\%20UWr\%20do\%20nowelizacji\%20kodeksu\%20karnego.pdf (dostęp: 26.02.2020); dalej: opinia KPKM UWr. 
preferencje prawodawcy racjonalnego są asymetryczne i jednocześnie przechodnie $^{19}$. Formułuje się również postulat należytego uporządkowania systemu wartości stanowiących podstawę decyzji ustawodawcy ${ }^{20}$. Tymczasem już pobieżna analiza ustawy nowelizującej kodeks karny dostarcza niezbyt optymistycznych spostrzeżeń co do urzeczywistnienia tego założenia. Warto w tym miejscu wskazać przykłady najbardziej wyraziste, zapewniając jednocześnie, że nie są to przypadki odosobnione.

Niewątpliwie jako trudne do zaakceptowania z perspektywy spójności aksjologicznej okazałoby się wprowadzenie do kodeksu karnego art. $57 \mathrm{~b}^{21}$ przewidującego nadzwyczajne obostrzenie kary — i to zarówno w zakresie dolnej, jak i górnej granicy ustawowego zagrożenia - w wypadku dopuszczenia się przez sprawcę czynu zabronionego kwalifikowanego z art. 12 § 1 k.k., a zatem w warunkach czynu ciągłego. Przepis ten w sposób całkowicie niezrozumiały znacznie uprzywilejowuje sprawcę popełniającego kilka przestępstw względem sprawcy, który dopuszcza się dwu lub więcej zachowań spiętych klamrą czynu ciągłego ${ }^{22}$. Nietrudno zauważyć, że aktualnie kodeks karny nie przewiduje tak drastycznego, bo przecież aż dwukrotnego, podwyższenia górnej granicy ustawowego zagrożenia karą przy jednoczesnym zobowiązaniu sądu do orzeczenia kary powyżej dolnej granicy tego zagrożenia. Co więcej, w pierwotnej wersji projektu przewidywano też, że dolna granica ustawowego zagrożenia miałaby zostać zwiększona o połowę. Tymczasem niepodobna sensownie uzasadnić, dlaczego czyn popełniony „na raty” miałby się charakteryzować — abstrakcyjnie rzecz ujmując — dwukrotnie wyższym stopniem społecznej szkodliwości, z którym wszak powinny korespondować granice możliwej do wymierzenia kary. Spostrzeżenie to uderza szczególnie w odniesieniu do tych przypadków, w których ujmowane jednostkowo zachowania sprawcy (przed ich połączeniem klamrą czynu ciągłego) samodzielnie nie realizują jeszcze znamion czynu zabronionego. Gdyby ustawa weszła w życie, w wypadku popełnienia przez sprawcę czynu o stosunkowo niskim ciężarze gatunkowym w warunkach czynu ciągłego groziłaby mu kara o wiele surowsza niż sprawcy, który dopuścił się czynu cechującego się dużo większą społeczną szko-

19 Co do tego i kolejnych założeń charakteryzujących racjonalnego prawodawcę zob. L. Nowak, Interpretacja..., s. 39 n.; idem, Próba..., s. 67 n.

20 J. Wróblewski, op. cit., s. 223 n.; B. Janiszewski, op. cit., s. 21.

21 Artykuł 57b k.k. w kształcie przewidzianym przez ustawę nowelizującą (to jest po poprawkach Senatu) przyjął brzmienie: „Skazując za przestępstwo określone w art. 12 § 1, sąd wymierza karę przewidzianą za przypisane sprawcy przestępstwo w wysokości powyżej dolnej granicy ustawowego zagrożenia do podwójnej wysokości górnej granicy ustawowego zagrożenia".

22 A. Barczak-Oplustil et al., Opinia do uchwały Senatu Rzeczpospolitej Polskiej z dnia 24 maja 2019 r. w sprawie ustawy o zmianie ustawy - Kodeks karny oraz niektórych innych ustaw, uchwalonej przez Sejm Rzeczpospolitej Polskiej na 81. posiedzeniu w dniu 16 maja 2019 r., s. 53-54, https://www. rpo.gov.pl/sites/default/files/Opinia\%20Krakowskiego\%20Instytutu\%20Prawa\%20Karnego\%20 Fundacja\%20ws.\%20poprawek\%20Senatu\%209\%20czerwca\%202019.pdf (dostęp: 26.02.2020); dalej: opinia KIPK z 9 czerwca 2019 roku; zob. też opinię KPKM UWr, s. 15-19. 
dliwością 23 - przykładowo sprawcy wypadku drogowego ze skutkiem śmiertelnym groziłaby kara do 8 lat pozbawienia wolności, natomiast sprawcy, który czynem ciągłym dokonał „,szczególnie zuchwałej” kradzieży na łączną kwotę kilkuset złotych, groziłaby już kara do aż 16 lat pozbawienia wolności ${ }^{24}$.

Warto w tym kontekście zauważyć, że o ile zdawać by się mogło, że ustawodawca uważa życie, zdrowie ludzkie oraz szeroko rozumianą wolność osobistą za jedne $\mathrm{z}$ najdonioślejszych dóbr chronionych prawem, o tyle po ewentualnym wejściu w życie ustawy nowelizującej proporcja ta zostałaby zachwiana. Wskutek noweli spora część przestępstw przeciwko mieniu okazałaby się zagrożona karą nieporównywalnie większą niż czyny godzące w owe podstawowe dobra. Trudno zaś — jak wskazano w opinii KIPK z 9 czerwca 2019 roku — znaleźć usprawiedliwienie dla sytuacji, w której znacznie surowszą karą zagrożone są przestępstwa skierowane przeciwko mieniu o wartości większej niż dziesięciokrotność kwoty określającej mienie wielkiej wartości niż przykładowo przestępstwo handlu ludźmi, polegające wszak na traktowaniu człowieka jako przedmiot własności ${ }^{25}$.

Kolejna część założeń formułowanych w odniesieniu do racjonalności prawodawcy ma charakter merytoryczny i dotyczy jego faktycznej wiedzy. W tym kontekście wskazuje się przede wszystkim, że prawodawca winien dysponować wiedzą umożliwiającą dokonanie rzetelnej diagnozy wyjściowego stanu rzeczy w dziedzinie podlegającej unormowaniu, a w konsekwencji pozwalającą na ustalenie, czy w ogóle konieczna jest jakakolwiek ingerencja w zastany stan rzeczy. Konkretyzując nieco tę myśl, przyjmuje się, że kryminalizacja jest racjonalna wówczas, gdy według zamiaru ustawodawcy ma wywołać określone skutki. Pośród powodów nieracjonalnych zaś wymienia się powody emocjonalne, przy których ustawodawca powołuje się na intuicyjnie odczuwaną karygodność określonego typu zachowań ${ }^{26}$. W uzasadnieniu projektu ustawy nowelizującej czytamy tymczasem, że

obecny stan prawny, funkcjonujący w ramach dotychczasowej polityki karnej, nie tylko nie odpowiada postulatom wynikającym z funkcji ochronnej prawa karnego, ale i nie pozwala zaspokoić społecznego poczucia bezpieczeństwa i sprawiedliwości, głównie z uwagi na zbyt niski wymiar kar. Dodatkowo wadliwa konstrukcja niektórych instrumentów prawa karnego uniemożliwia osią-

23 Więcej przykładów w opinii KIPK z 9 czerwca 2019 roku, s. 52-53.

24 Przykład przytoczony za opinią KIPK z 9 czerwca 2019 roku, s. 42. W projekcie przewidziano bowiem nowy typ czynu zabronionego w postaci kradzieży szczególnie zuchwałej (art. 278a k.k.), nawiązującej do typu czynu zabronionego znanego kodeksowi karnemu z 1969 roku, skądinąd krytykowanego za niedostateczną określoność znamion modyfikujących. Szerzej zob. A. Barczak-Oplustil et al., Opinia w sprawie uchwalonej przez Sejm Rzeczypospolitej Polskiej na 81. posiedzeniu w dniu 16 maja 2019 r. ustawy o zmianie ustawy - Kodeks karny oraz niektórych innych ustaw, s. 25-26, https://www.rpo.gov.pl/sites/default/files/Opinia\%20Krakowskiego\%20Instytutu\%20 Prawa\%20Karnego\%2C\%2020\%20maja\%202019.pdf (dostęp: 28.02.2020); dalej: opinia KIPK z 20 maja 2019 roku.

25 Opinia KIPK z 9 czerwca 2019 roku, s. 41-42.

26 B. Janiszewski, op. cit., s. 13; L. Gardocki, Zagadnienia teorii kryminalizacji, Warszawa 1990, s. $76 \mathrm{n}$.

Przegląd Prawa i Administracji CXX, 2020, cz. 1 i 2

(C) for this edition by CNS 
ganie pożądanych i oczekiwanych rezultatów w zakresie polityki karnej, w szczególności zwiększenia liczby orzekanych kar wolnościowych za przestępstwa drobne i średniej wagi, w miejsce kary pozbawienia wolności ${ }^{27}$.

Zgodnie zatem z diagnozą projektodawcy ochrona gwarantowana obecnie przez prawo karne podstawowym dobrom, takim jak życie, zdrowie czy wolność, jawi się jako niewystarczająca, społeczne poczucie bezpieczeństwa i sprawiedliwości jest niezaspokojone z uwagi na zbytnią łagodność przewidzianych przez ustawę karną sankcji, a niektóre z instrumentów prawnokarnych funkcjonują w sposób wadliwy. Rzecz jednak w tym, że przytoczone w uzasadnieniu dane statystyczne pochodzą z 2016 roku, a więc sprzed bez mała trzech lat przed przedstawieniem Sejmowi projektu ustawy nowelizującej. Inna sprawa, że nawet w obliczu tych danych nie sposób zrozumieć spostrzeżenia, jakoby mechanizmy pozwalające na orzekanie kar wolnościowych zamiast kary pozbawienia wolności skonstruowane były w sposób wadliwy. Wszak w latach, z których pochodzą przedstawione przez projektodawcę dane, liczba orzekanych kar pozbawienia wolności spadła w sposób drastyczny, bo o ponad połowę. Jednocześnie w porównaniu z 2014 rokiem w 2016 orzeczono o jedną trzecią więcej kar grzywny oraz o prawie połowę więcej kar ograniczenia wolności ${ }^{28}$. Projektodawca nie wskazał przy tym, które z obowiązujących rozwiązań miałyby rzekomo uniemożliwiać szersze stosowanie kar wolnościowych.

Za argument rozstrzygający, przemawiający za koniecznością nowelizacji kodeksu karnego, projektodawca uznał wyniki badania Centrum Badania Opinii Społecznej przeprowadzonego między 2 a 9 lutego 2017 roku. Jak wskazano, na pytanie „czy Pana(-i) zdaniem, ogólnie rzecz biorąc, lepiej byłoby, gdyby w Polsce kary dla łamiących prawo były surowsze?" niemal trzy czwarte ogółu ankietowanych odpowiedziało w sposób twierdzący ${ }^{29}$. Abstrahując od tego, czy modyfikacja szczegółowych instrumentów prawnokarnych odbywać się powinna na podstawie tego rodzaju, pozostającej na bardzo wysokim poziomie ogólności ankiety, trudne do zaakceptowania wydaje się wprowadzanie zmiany normatywnej tylko po to, aby zaspokoić czyjeś — z natury rzeczy subiektywne — odczucia czy szerzej nieuzasadnione oceny. Projektodawca w tym wypadku wskazuje zaś wprost, że celem nowelizacji jest ,zaspokojenie społecznego poczucia sprawiedli-

27 Druk sejmowy Sejmu Rzeczypospolitej Polskiej VIII Kadencji nr 3451 z dnia 14 maja 2019 roku. Ocena skutków regulacji z dnia 5 kwietnia 2019 roku dotycząca projektu ustawy o zmianie ustawy - Kodeks karny oraz niektórych innych ustaw, s. 4, http://orka.sejm.gov.pl/Druki8ka.nsf/0/996CE307123D03FEC12583FA0069E8F2/\%24File/3451.pdf(dostęp: 26.02.2019); dalej: ocena skutków regulacji.

28 Por. ibidem, s. 3.

29 Ibidem, s. 4; zob. komunikat Centrum Badania Opinii Społecznej nr 31/2017 dotyczący badania „Społeczne oceny wymiaru sprawiedliwości”, s. 3, https://www.cbos.pl/SPISKOM. POL/2017/K_031_17.PDF (dostęp: 26.02.2020). 
wości" ${ }^{30}$. U podstaw każdej nowelizacji, a zatem tym bardziej u podstaw zmiany prawa noszącej znamiona reformy, leżeć wszak powinna potrzeba rozwiązania zidentyfikowanych w sposób rzetelny problemów społecznych - w przeciwnym razie prawodawca będzie nieuchronnie zmierzać w kierunku populizmu penalnego. Tymczasem trudno oprzeć się wrażeniu, że wyniki przeprowadzonego badania — wobec maksymalnego stopnia ogólności zadanego pytania — nie mogą dostarczać odpowiedniej wiedzy o rzeczywistości społecznej. Dotyczy ono bowiem oceny w żaden sposób niezrelatywizowanej i tym samym nie pozwala na poczynienie ustalenia, ani pod jakim względem, ani z jakiego powodu miałoby „być lepiej”, gdyby w Polsce „kary dla łamiących prawo były surowsze”. Niepodobna przy tym określić, czy sformułowanie o „surowszych karach” odnosi się do ustawowego wymiaru kary, jej wymiaru sądowego, czy też może obu tych sfer.

Nasuwa się w związku z tym obawa, że wątpliwe jest, aby projektodawca dysponował wiedzą, która pozwalałaby mu na możliwie pełne ustalenie rzeczywistego obrazu stosunków społecznych w sferze, która miała zostać dotknięta zmianą normatywną. Warto w tym miejscu wskazać chociażby na fakt, iż właśnie w 2019 roku odnotowano bardzo wysoki, bo sięgający prawie 90\%, wskaźnik poczucia bezpieczeństwa wśród Polaków, a także zaobserwowano rekordowo wysokie poczucie bezpieczeństwa w miejscu zamieszkania ${ }^{31}$. Samo już to spostrzeżenie w sposób istotny nadwątla siłę najważniejszego argumentu projektodawcy, odnoszącego się do konieczności wzmocnienia poczucia bezpieczeństwa u obywateli, a i to przy przychylnym projektodawcy założeniu, że „zaspokajanie poczucia", czyli - jakby nie patrzeć - uleganie emocjom, powinno być czynnikiem determinującym modyfikację przepisów prawnokarnych ${ }^{32}$. Rzecz bowiem w tym, że tworzenie prawa powinno być działalnością — używając określenia T. Kaczmarka — racjonalną, a zatem „wytrawioną z pierwiastków magicznych"33.

Wiedza racjonalnego prawodawcy powinna nadto pozwalać na sformułowanie możliwie trafnych prognoz co do tego, czy i w jakim stopniu ustanowienie norm o projektowanej treści faktycznie wpłynie na ich adresatów. Prawodawca — aby jego aktywność mogła szczycić się przymiotem racjonalności w ujęciu instrumentalnym — musi być zatem w stanie stwierdzić, czy zamierzone cele można w ogóle osiągnąć za pomocą środków oddziaływania prawnego, a jeśli odpowiedź na tak postawione pytanie jest twierdząca, to winien wskazać, jakie rozwiązania prawne potencjalnie na to pozwolą. Kolejnym etapem pozostaje natomiast wy-

30 Uzasadnienie projektu, s. 1 i 22. Szerzej zob. opinia KPKM UWr, s. 4.

3190 proc. rodaków uważa, że w Polsce żyje się bezpiecznie, https://www.tvp.info/42849220/ 90-proc-rodakow-uwaza-ze-w-polsce-zyje-sie-bezpiecznie (dostęp: 26.02.2020); komunikat Centrum Badania Opinii Społecznej nr 72/2019 dotyczący badania „Opinie Polaków o bezpieczeństwie w kraju i okolicy”, https://cbos.pl/SPISKOM.POL/2019/K_072_19.PDF (dostęp: 26.02.2020).

32 Szerzej zob. opinia KPKM UWr, s. 4.

33 T. Kaczmarek, Racjonalny ustawodawca wobec opinii społecznej a populizm penalny, [w:] Populizm penalny i jego przejawy w Polsce, red. Z. Sienkiewicz, R. Kokot, Wrocław 2009, s. 36-37. 
bór środka najskuteczniejszego — a zatem najefektywniejszego — ze wszystkich dostępnych. Wydaje się, że również w tym zakresie w odniesieniu do analizowanej ustawy nowelizującej projektodawca nie uczynił zadość wymogom modelu racjonalnego tworzenia prawa. Nie wskazano bowiem jakichkolwiek alternatywnych sposobów osiągnięcia zamierzonych celów, poprzestając na stwierdzeniu, iż rekomendowanym rozwiązaniem jest zwiększenie stopnia punitywności, obejmujące cztery obszary działań — zmiany w części ogólnej kodeksu karnego, zmiany w zakresie sankcji karnych, ustanowienie nowych typów czynów zabronionych oraz zmiany w tak zwanym pozakodeksowym prawie karnym ${ }^{34}$. Co więcej, na kartach uzasadnienia projektu nie sposób doszukać się podstaw wniosku, że globalne podwyższenie kar możliwych do orzeczenia za bardzo zróżnicowane przestępstwa faktycznie wpłynie na realne zwiększenie ochrony najwyżej wycenianych dóbr bądź też wzmocni — pozostające wszak na bardzo wysokim poziomie - poczucie bezpieczeństwa obywateli. Swoisty schemat myślowy, zgodnie z którym surowsza kara wprost przekłada się na pełniejszą (a przede wszystkim efektywniejszą) ochronę dóbr prawnych, zdaje się zaś stanowić zbyt daleko idące uproszczenie ${ }^{35}$.

Racjonalny prawodawca powinien w końcu uwzględniać koszty przedsiębranych działań prawotwórczych. Koszty te można rozumieć nie tylko w ujęciu ekonomicznym, lecz także jako koszt społeczny czy organizacyjny. Odnosząc się w tym miejscu wyłącznie do kosztów ekonomicznych, należy zauważyć, że projektodawca nie tylko nie wskazuje, z jakiego rodzaju obciążeniami fiskalnymi będą się wiązać proponowane zmiany - a mając na uwadze zasadniczy wzrost punitywności sytemu można przewidywać, że koszty związane zwłaszcza z wykonywaniem długoterminowych kar pozbawienia wolności znacząco wzrosną ${ }^{36}$ — ale z rozbrajającą wręcz szczerością stwierdza, iż prace nad dokonaniem tego rodzaju precyzyjnej analizy dopiero trwają i zostaną przedstawione w przyszłości ${ }^{37}$. Niezależnie od tego, że projektodawca oddala się w ten sposób od ideału racjonalności, podzielić należy wątpliwości co do dochowania standardu wyznaczonego przez art. 118 ust. 3 Konstytucji, który wszakże wymaga od projektodawcy przedkładającego Sejmowi projekt ustawy przedstawienia skutków finansowych jej wykonania ${ }^{38}$.

${ }^{34}$ Uzasadnienie projektu, s. 1; ocena skutków regulacji, s. 5.

35 Tak: J. Giezek, K. Lipiński, op. cit., s. 4.

36 Przy czym w tym kontekście w zasadzie nie można mówić — tak jak to czyni projektodawca — o jedynie ewentualnym wzroście kosztów dla Służby Więziennej, lecz wyłącznie o wzroście pewnym - ocena skutków regulacji, s. 15.

37 Ibidem, s. 16: „dokonanie precyzyjnych szacunków w tym zakresie wymaga pozyskania szczegółowych danych, w związku z czym OSR zostanie w tej materii uzupełniony niezwłocznie po ich otrzymaniu. W Ministerstwie Sprawiedliwości trwają prace mające na celu pozyskanie i analizę informacji niezbędnych do wskazania skutków finansowych projektowanych rozwiązań".

38 Opinia KIPK z 20 maja 2019 roku, s. 44. 
Zbliżamy się tym samym do założeń dotyczących wiedzy prawodawcy o danym systemie prawnym, w tym o zasadach wprowadzania norm do systemu prawnego ${ }^{39}$. I w tym jednak wypadku skonfrontowanie ustawodawcy faktycznego z ideałem, do którego powinien dążyć, wystawia nie najlepsze świadectwo pierwszemu z nich. Rzecz bowiem w tym, że — jak wskazuje Krakowski Instytut Prawa Karnego - ustawa nowelizująca została uchwalona z naruszeniem wynikającego z rozdziału 4 Regulaminu Sejmu specjalnego trybu postępowania legislacyjnego z projektami nowelizacji ustaw o randze kodeksów, który wskazuje, w jakim terminie minimalnym mogą się odbyć poszczególne czytania projektu tego rodzaju ustawy w Sejmie ${ }^{40}$. Rzecz bowiem w tym, że prawodawca jako racjonalny organizator procesu legislacyjnego winien stwarzać takie warunki dla prac nad ustawą, aby na każdym ich etapie zapewniona była możliwość przede wszystkim wszechstronnej krytycznej analizy proponowanych rozwiązań w celu zapewnienia ich spójności i rzecz jasna racjonalności ${ }^{41}$. Tego rodzaju oczekiwanie jawi się jako szczególnie uzasadnione właśnie w wypadku prac nad aktami prawnymi o randze kodeksowej. Tymczasem w przypadku analizowanej ustawy już tylko sama liczba (42) i obszerność poprawek wprowadzonych przez Senat — których spora część budzi wątpliwości co do zgodności z Konstytucją z uwagi na wykroczenie poza materię ustawy uchwalonej przez $\operatorname{Sejm}^{42}$ — świadczy o tym, że również w tym względzie prawodawca faktyczny znacznie oddala się od modelu prawodawcy racjonalnego.

Jest oczywiste, że poszczególne założenia składające się na model racjonalnego prawodawcy mają charakter idealizacyjny, a tym samym kontrfaktyczny. Od prawodawcy faktycznego, a na początkowym etapie tworzenia aktu prawnego — od jego projektodawcy, można wszelako wymagać, aby w procesie projektowania, a następnie uchwalania ustawy kierował się przede wszystkim zasadą racjonalności. Całkowicie uzasadnione byłoby zatem wymaganie odeń określenia celu działalności prawotwórczej opartego na rzetelnym zdiagnozowaniu stanu faktycznego, rozważnego wyboru potencjalnych środków prawnych do realizacji tego celu, a w końcu wprowadzenia nowych norm do porządku prawnego w odpowiednim trybie.

Skonfrontowanie ustawy nowelizującej kodeks karny z 13 czerwca 2019 roku oraz leżącego u jej podstaw projektu wraz z uzasadnieniem z modelem działalności prawodawczej, do którego ustawodawca faktyczny powinien dążyć, nie pozwala na wystawienie wysokiej noty ustawie aktualnie poddawanej kontroli przez Trybunał Konstytucyjny. Pokusić się można wręcz o stwierdzenie, że stopień oddalenia od poszczególnych elementów modelu racjonalnego stanowienia

39 Zob. S. Wronkowska, op. cit., s. 123-124.

40 Opinia KIPK z 20 maja 2019 roku, s. 50-52. Zob. też opinię KIPK z 9 czerwca 2019 roku, s. $8 \mathrm{n}$.

41 Zob. S. Wronkowska, op. cit., s. 127-128.

42 Opinia KIPK z 9 czerwca 2019 roku, s. 15 n. 
prawa nakazywałby alternatywnie uznać, że faktycznemu projektodawcy nie sposób przypisać cechy racjonalności - co wszak stanowi jeden z najmocniejszych argumentów możliwych do sformułowania w argumentacji prawniczej ${ }^{43}$ - albo też przyjąć, że rzeczywisty cel projektodawcy różni się jednak od deklarowanego. Rzecz bowiem w tym, że populizm penalny wyznacza cele polityki karnej oraz racjonalne środki do ich realizacji, lecz od tradycyjnie ujmowanego „racjonalizmu” prawa karnego (jeśli byśmy chcieli go przeciwstawić populizmowi) odróżnia go treść wyznaczonych celów ${ }^{44}$. Niestety żadna z tych konkluzji nie przedstawia się jako szczególnie optymistyczna.

\title{
THE ISSUE OF (UN)RATIONALITY OF THE AUTHOR OF DRAFT LAW IN THE EXAMPLE OF SELECTED PROVISIONS OF THE ACT OF 13TH JUNE 2019 AMENDING THE CRIMINAL CODE
}

\author{
Summary
}

\begin{abstract}
Starting with the analysis of the assumption of rational legislator, the authors attempt to relate the decoded standard to the specifics of criminal law. In their further considerations, which are based on the content of the draft Act of June 13th, 2019 amending the Criminal Code and other acts, they focus on the issue of (un)rationality of the author of draft law and the subsequent postulates formulated towards the actual legislator.
\end{abstract}

Keywords: criminal law, criminal code, author of draft law, rationality, rational legislator

\section{BIBLIOGRAFIA}

Filar M., „Druga” nowelizacja kodeksu karnego dotyczaca tzw. przestępstw seksualnych, „Państwo i Prawo" 2006, nr 3.

Gardocki L., Zagadnienia teorii kryminalizacji, Warszawa 1990.

Janiszewski B., Rozważania o „racjonalności” w dziedzinie prawa karnego, „Ruch Prawniczy, Ekonomiczny i Socjologiczny" 1996, nr 4.

Kaczmarek T., Racjonalny ustawodawca wobec opinii spotecznej a populizm penalny, [w:] Populizm penalny i jego przejawy w Polsce, red. Z. Sienkiewicz, R. Kokot, Wrocław 2009.

Kantor-Kozdrowicki P., Racjonalność prawodawcy jako paradygmat nauk prawnych, „Folia Iuridica Universitatis Wratislaviensis" 7, 2018.

Kardas P., Giezek J., Nowa filozofia karania, czyli o założeniach i zasadniczych elementach nowelizacji kodeksu karnego, „Palestra” 2015, nr 7-8.

Kotarbiński T., Traktat o dobrej robocie, Wrocław-Warszawa-Kraków-Gdańsk-Łódź 1982.

Lang W., Wróblewski J., Zawadzki S., Teoria państwa i prawa, Warszawa 1986.

43 B. Janiszewski, op. cit., s. 11.

44 W. Wróbel, Czy powrót do racjonalizmu? Projekty nowelizacji kodeksu karnego w perspektywie zmian dokonanych w prawie karnym w latach 2005-2007, [w:] Populizm..., s. 104. 
Nowak L., Interpretacja prawnicza. Studium z metodologii prawoznawstwa, Warszawa 1973.

Nowak L., O ukrytej jedności nauk społecznych i nauk przyrodniczych, „Nauka” 1998, nr 1.

Nowak L., Próba metodologicznej charakterystyki prawoznawstwa, Poznań 1968.

Szkice z teorii prawa i szczegółowych nauk prawnych, red. S. Wronkowska, M. Zieliński, Poznań 1990.

Wprowadzenie do nauk prawnych. Leksykon tematyczny, red. A. Bator, Warszawa 2008.

Wronkowska S., Prawodawca racjonalny jako wzór dla prawodawcy faktycznego, [w:] Szkice z teorii prawa i szczegółowych nauk prawnych, red. S. Wronkowska, M. Zieliński, Poznań 1990.

Wróbel W., Czy powrót do racjonalizmu? Projekty nowelizacji kodeksu karnego w perspektywie zmian dokonanych $w$ prawie karnym w latach 2005-2007, [w:] Populizm penalny i jego przejawy w Polsce, red. Z. Sienkiewicz, R. Kokot, Wrocław 2009.

Wróblewski J., Teoria racjonalnego tworzenia prawa, Warszawa 1985.

Zoll A., Potrzeba racjonalności w reformowaniu prawa karnego, [w:] Teoretyczne i praktyczne problemy współczesnego prawa karnego, red. T. Bojarski, A. Michalska-Warias, I. Nowikowski, K. Nazar-Gutowska, J. Piórkowska-Fliegier, D. Firkowski, Lublin 2011. 